\title{
Avian malaria in introduced, native and endemic New Zealand bird species in a mixed ecosystem
}

\author{
Danielle C. Sijbranda ${ }^{1 *}$, Jim Campbell ${ }^{2}$, Brett D. Gartrell ${ }^{1}$, Laryssa Howe ${ }^{1}$ \\ ${ }^{1}$ Wildbase, Institute of Veterinary, Animal and Biomedical Sciences, Massey University, Private Bag 11 222, Palmerston North \\ 4442, New Zealand \\ ${ }^{2}$ Department of Conservation, 34-36 Taupo Quay, Whanganui 4500, New Zealand \\ *Author for correspondence: (E-mail: sijbdaantje@hotmail.com)
}

Published online: 3 September 2015

\begin{abstract}
Avian malaria, caused by Plasmodium spp., has been reported as a cause of morbidity and mortality in New Zealand bird populations. The prevalence of Plasmodium lineages in the Waimarino Forest was evaluated in NZ robins (Petroica longipes), other passerines, blue ducks (Hymenolaimus malacorhynchos), and brown kiwi (Apteryx mantelli), using nested PCR. The presence of $P$. sp. lineage LINN1, $P$. (Huffia) elongatum lineage GRW06 and $P$. (Novyella) sp. lineage SYAT05 was demonstrated; Plasmodium (Haemamoeba) relictum lineage GRW4 was not found. The highest prevalence of infection was found in introduced European species (80.5\%), followed by native (19\%) and endemic species (3.5\%), with a significant difference between these groups. All detected Plasmodium lineages have previously been identified in New Zealand and introduced species have been suggested as an important reservoir of infection. The results of this study will aid New Zealand conservation managers with disease risk management during bird translocations from the Waimarino forest.
\end{abstract}

Key words: elongatum; GRW4; GRW06; LINN1; Plasmodium; relictum; robin; SYAT05; translocation; Waimarino

\section{Introduction}

New Zealand's ecosystems are considered to be among the most extinction-prone in the world (Myers et al. 2000; Brooks et al.2002). Due to its high proportion of bird-pollinated plants, New Zealand's terrestrial ecosystems are considered especially sensitive to losses in native bird biodiversity (Sekercioglu et al. 2004). Many New Zealand bird populations are critically endangered (Hitchmough et al. 2007) and efficient wildlife management strategies have been employed (Craig et al. 2000) to safeguard their long-term viability and sustain them as essential functional components of the terrestrial ecosystems. Ongoing predation and habitat changes since European settlement in New Zealand have contributed to population declines in many bird species (O'Donnell 1996; Bogich et al. 2012) even in those still not considered at risk. For example, New Zealand robins (Petroica longipes) (henceforth NZ robins) are currently considered to be 'not threatened' (Robertson etal. 2013), despite the IUCN reporting a decreasing population trend for this species (IUCN 2014). Moreover, the distribution pattern of NZ robins has changed from being once widespread throughout the mainland to a patchy distribution (Heather \& Robertson 2005). Translocation in the form of assisted colonisation of a new area with suitable habitat is a successful management tool to secure NZ robin numbers (Taylor et al. $2005)$. According to the IUCN guidelines, monitoring and management of disease should be standard practice when populations are translocated to both maximise the health of translocated birds and minimise the risk of introducing new pathogens to a destination area (IUCN/SSC 2013). Therefore, identification of previously unrecorded pathogens and spatial and temporal tracking of existing pathogens is beneficial for New Zealand conservation managers and provides a rational basis for disease risk management during translocations (Parker et al. 2006).
Avian malaria, caused by various Plasmodium species, is an emerging disease in New Zealand (Schoener et al. 2014). A high mortality outbreak occurred after translocation of South Island saddlebacks (Philesturnus carunculatus) due to concurrent Plasmodium spp. and avipox virus infection (Alley et al. 2010). Furthermore, infection with Plasmodium spp. was the confirmed cause of death in five out of eight yellowheads (Mohoua ochrocephala) that died after being moved from an area with low Plasmodium spp. prevalence to a location with very high prevalence of both the parasite and the appropriate vector (Alley et al. 2008). Other wild bird species in which avian malaria-related mortalities have been documented are brown kiwi (Apteryx mantelli) (Banda et al. 2013), great spotted kiwi (Apteryx haastii) (Howe et al. 2012), stitchbird (Notiomystis cincta) (Howe et al. 2012), and New Zealand dotterel (Charadrius obscurus) (Reed 1997). Currently, 17 lineages of Plasmodium spp. have been reported in 35 New Zealand wild bird species, including introduced, native, and endemic species (Schoener et al. 2014). The most commonly detected lineages are $P$. (Huffia) elongatum lineage GRW06 and $P$. (Novyella) sp. lineage SYAT05, followed by $P$. (Haemamoeba) relictum (lineages GRW4 and SGS1) and $P$. sp. lineage LINN1, while $P$. (Novyella) lineage AFTRU08 and $P$. (Haemamoeba) relictum lineage LINOLI01 are rare (Schoener et al. 2014). All of these lineages are considered to be non-endemic to New Zealand and were likely introduced into this country with the importation of their avian hosts (Ewen et al. 2012).

Pre-translocation health screening of $20 \mathrm{NZ}$ robins from the Waimarino Forest was undertaken by the Greater Wellington Regional Council in 2011. Health screens comprised physical checks for external lesions of avipoxvirus infection, cloacal swabs for bacterial culture of Salmonella and Yersinia, and blood sample collection for Plasmodium spp. PCR. The only detected pathogen of concern for translocation was $P$. relictum 
lineage GRW4, which was detected in one NZ robin, while two NZ robins were infected with $P$. elongatum lineage GRW06 (Nikki McArthur, Greater Wellington Regional Council, pers. comm.). Plasmodium elongatum lineage GRW06 is widespread in New Zealand and has been found in a large variety of bird species (Alley et al. 2010; Baillie \& Brunton 2011; Castro et al. 2011; Marzal et al. 2011; Ewen et al. 2012; Howe et al. 2012; Banda et al. 2013). Although sporadic deaths due to this lineage have been reported in wild birds in New Zealand (Howe et al. 2012; Banda et al. 2013), its pathogenicity in wild birds worldwide is generally considered to be low (Valkiunas 2005). Plasmodium relictum lineage GRW4 is considered to be much more pathogenic. This lineage played an important role in the extinction of many endemic bird species in Hawaii. The establishment of the $P$. relictum lineage GRW4 on the Hawaiian Islands, following the introduction of its mosquitovector Culex quinquefasciatus and exotic avian hosts, caused a rapid spread of this lineage amongst the endemic avifauna with catastrophic results (van RiperIII et al. 1986). In Hawaiian bird species that survived, such as the apapane (Himatione sanguinea), high mortality is still a problem (Atkinson \& Samuel 2010). In New Zealand, this lineage has been identified in wild birds in the northern part of the North Island, including one red-fronted parakeet (Cyanoramphus novaezelandiae) from Little Barrier Island (Ortiz-Catedral et al. 2011) and 17 house sparrows (Passer domesticus) from Drury, Titiritiri Matangi and Little Barrier Island (Marzal et al. 2011; Ewen et al. 2012). The geographical spread of $P$. relictum lineage GRW4 and its impact on New Zealand's endemic and native bird species are currently not well understood. Therefore, the translocation of NZ robins from the Waimarino Forest was halted until the risk of spreading Plasmodium lineages to new areas could be further evaluated.

The aim of this study was to evaluate the presence and prevalence of Plasmodium lineages in NZ robins and other bird species in the Waimarino Forest area, as part of the assessment of the area's suitability as a mainland donor site for North Island robin translocations. In addition, routine conservation management activity allowed for opportunistic surveying for Plasmodium spp. in brown kiwi and blue duck (Hymenolaimus malacorhynchos) living in the area.

\section{Materials and methods}

\section{Study site}

Our study area, the Waimarino Forest, is located in the central North Island of New Zealand (39 $26^{\prime} 17.66^{\prime \prime}$ S, $175^{\circ} 8^{\prime} 24.76^{\prime \prime}$ E). It is a privately owned area of 6937 ha, of which 3884 ha are planted in exotic pine (Pinus radiata) for logging. The remaining land is made up of indigenous forest, streams, riparian margins, landslip scars and farmland. It is bordered on the south side by the road from Raetihi to Pipiriki, on the north side by the Manganui o te Ao River, a conservation site for the nationally endangered blue duck, and on the west side by the Whanganui River (Fig. 1). Its west side also borders the Whanganui National Park (39 $34^{\prime} 59.88^{\prime \prime}$ S, $175^{\circ} 4^{\prime} 59.88^{\prime \prime}$ $\mathrm{E})$, one of the largest remaining tracts of lowland forest with streams and rivers in the North Island. As a consequence, Plasmodium lineages found in the Waimarino Forest will also have an impact on birds in the Whanganui National Park (Fig. 1). The mixed landscape within the Waimarino Forest results in adjoining areas with various densities of endemic, native and introduced European bird species within the study site. Among the many endemic species, established breeding populations of NZ robins and brown kiwi are present, which have both been used as source populations for translocations. In 1999, 40 NZ robins were moved to Paengaroa Mainland Island and in 2001, 28 NZ robins were moved to Bushy Park Reserve (Armstrong 2010). Although precise NZ robin counts are lacking, the number of NZ robins in the area is estimated at ca. 1000 individuals, based on a 3-day survey by staff from the Greater Wellington Regional Council in 2010. The population is well established and expected to replenish its numbers easily after removal of up to 60 birds for translocation.

For the purpose of this study, the Waimarino Forest, bordering areas of the Whanganui National Park, and farmland surrounding Pipiriki were treated as one epidemiological unit.

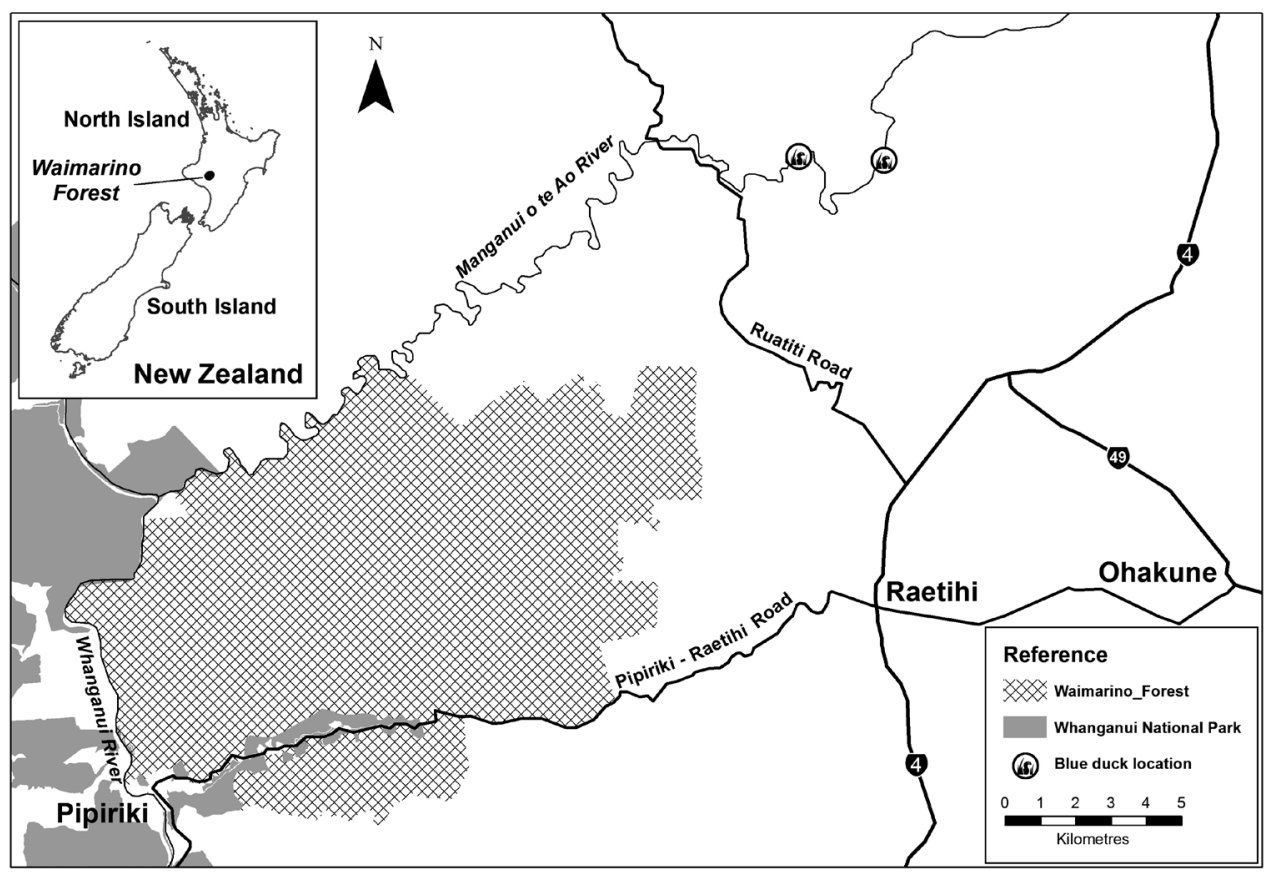

Figure 1. Location of the Waimarino Forest within New Zealand and its relation to surrounding geographical features. 
Therefore, we assumed that birds within this area were exposed to similar lineages of Plasmodium spp.

\section{Blood sample collection and individual bird processing}

One hundred NZ robins were caught using clap-traps. Standard mist netting techniques were used to catch 88 passerines of various species (excluding robins) and 14 blue ducks. During spring sessions in the first week of October 2012, NZ robins and other passerines were caught in the western half of the forest. During summer sessions in the last week of February 2013, NZ robins were caught in the eastern and northern parts of the forest, while other passerines were caught close to the south-west border of the forest around the village of Pipiriki and neighbouring farmland (Fig. 1). Logging activities inside the Waimarino Forest determined which areas were available to the fieldwork team. The area near Pipiriki was chosen for mist netting during the second fieldwork week because of the higher density of exotic passerine birds in this area.

All passerines were processed at their capture site and identified with uniquely numbered metal leg bands. We collected blood samples using heparinised capillary tubes after puncturing the brachial vein with a sterile 27 gauge needle, ranging in volume from 0.05 to $0.25 \mathrm{ml}$ and equalling less than $1 \%$ of each bird's body mass. Body mass (to nearest $0.5 \mathrm{~g}$ ), tarsometatarsal length (to nearest $0.1 \mathrm{~mm}$ ) and wing chord (to nearest $0.5 \mathrm{~mm}$ ) were measured, and a physical health check was performed, before the birds were released. When possible, birds were classified as juvenile or adult, and as male or female according to their plumage characteristics. Individuals recaptured in mist nets were released immediately.

Blue duck blood samples of up to $1 \mathrm{ml}$ per bird were collected opportunistically during general health screens with the New Zealand Department of Conservation (DOC) in 2013 at two locations of the Manganui o te Ao River (Fig. 1) during mid-February $\left(39^{\circ} 18^{\prime} 42.900^{\prime \prime} \mathrm{S}, 175^{\circ} 16^{\prime} 48.301^{\prime \prime} \mathrm{E}\right)$ and mid-May (39 $\left.18^{\prime} 49.814^{\prime \prime} \mathrm{S}, 175^{\circ} 15^{\prime} 12.306^{\prime \prime} \mathrm{E}\right)$. Blood samples were collected using a sterile 27-gauge needle and 1-ml syringe and transferred to BD Microtainer ${ }^{\circledR}$ tubes with Lithium Heparin additive.

Packed cell volume (PCV) was determined for each blood sample on the day of blood collection, using a portable ZIPocrit haematocrit centrifuge (LW Scientific, Georgia, Australia) at $10000 \mathrm{rpm}$ for $5 \mathrm{~min}$, after which the samples were stored in BD Microtainer ${ }^{\circledR}$ tubes with Lithium Heparin additive at $-20^{\circ} \mathrm{C}$ until further processing.

To calculate a quantitative body condition index (BCI) for individual blackbirds (Turdus merula), silvereyes (Zosterops lateralis) and NZ robins, the following formula was used:

$$
\mathrm{BCI}=\frac{\text { body weight }(\mathrm{g})}{\text { tarsometatarsal length }(\mathrm{mm})}
$$

As part of an ongoing brown kiwi translocation project between the Waimarino Forest and Maungatautari Ecological Reserve $\left(38^{\circ} 01^{\prime} 00^{\prime \prime} \mathrm{S}, 175^{\circ} 34^{\prime} 00^{\prime \prime} \mathrm{E}\right), 20$ blood samples for pre-translocation health screens were collected from brown kiwi in the Waimarino Forest during 2012, 2013 and 2014. Results for Plasmodium spp. PCR were made available to us by Maungatautari Ecological Island Trust (MEIT).

\section{Molecular biology}

DNA was extracted using the DNeasy Blood and Tissue Kit (Qiagen, Valencia CA, USA), following the manufacturer's instructions for nucleated whole blood. Extracted DNA samples were stored at $-20^{\circ} \mathrm{C}$ until used for molecular analysis. The presence of the cytochrome $b$ gene of Plasmodium spp. was identified using a nested PCR using the primer sets HaemNF1/ HaemNR3 and HaemF/HaemR2 as described by Hellgren et al. (2004). A known Plasmodium positive blood sample, confirmed through sequencing as $P$. sp. lineage LINN1, was used as a positive control, while nuclease-free water was included as a negative control. To confirm successful amplification, the final PCR products were run on a $1.5 \%$ agarose gel (Invitrogen, Carlsbad, CA, USA) containing ethidium bromide for 1 hour at $100 \mathrm{~V}$.

Positive amplicons were purified using a PureLink PCR purification kit (Invitrogen, Auckland, New Zealand) and subjected to automatic dye-terminator cycle sequencing with the BigDyeTM Terminator Version 3.1 Ready Reaction Cycle Sequencing kit and the ABI3730 Genetic Analyzer (Applied Biosystems Inc., Foster City, CA, USA) to confirm the genomic sequences, using both the forward and reverse primers. Chromatograms were aligned using Geneious ${ }^{\mathrm{TM}}$ (Biomatters, Auckland, New Zealand) and examined for conspicuous overlapping peaks suggestive of Plasmodium spp. co-infection. The Plasmodium isolate sequences obtained were compared to other published sequences available from GenBank (Benson et al. 2014) using NCBI Blast and from the MalAvi database (Bensch et al. 2009).

\section{Statistics}

The apparent prevalence for Plasmodium spp. and the $95 \%$ confidence interval was determined for various groups and species of birds using the Epitools software, following the Wilson binomial approximation (Brown et al. 2001). Chisquare tests (Preacher 2001) were used to analyse whether prevalence of Plasmodium spp. differed significantly between various groups and species of birds. If the frequency in one or more bird categories was below five, a Fisher's exact test was used (Preacher \& Briggs 2001). Because data for BCI and PCV in the various bird species were not normally distributed, a non-parametric analysis (Mann-Whitney U tests, SPSS, version 22, IBM Statistics) was used to determine whether there was a significant difference in these parameters between Plasmodium spp. negative and positive birds.

\section{Results}

Blood samples were collected from 15 species in three different avian orders, of which 5 species are classified as introduced, 2 as native, and 8 as endemic to New Zealand (Table 1). All birds showed bright and alert behaviour and were in good physical condition. Overall, 45/222 (20.3\%) birds tested positive for the presence of Plasmodium DNA using nested PCR. The Plasmodium spp. prevalence for introduced bird species was $80.5 \%$ (33/41; 95\% CI $0.66-0.90)$, for native species $19 \%$ (7/37; 95\% CI 0.10-0.34) and for endemic New Zealand bird species $3.5 \%(5 / 144 ; 95 \%$ CI $0.02-0.08)$. The difference in prevalence of avian malaria infection between these three groups was significant $\left(\chi^{2}=60.04\right.$, d.f. $\left.=2, P<0.001\right)$.

DNA sequencing was successful for 30 out of 44 Plasmodium-positive passerine blood samples. For the remaining 15 samples sequencing failed due to the PCR product being too weak to sequence, or due to the presence of overlapping peaks throughout the sequence. In all 30 samples, 
Table 1. The prevalence of avian malaria in birds in the Waimarino Forest area and the Plasmodium lineages identified.

\begin{tabular}{|c|c|c|c|c|c|c|}
\hline Order & Family & Species* & $\begin{array}{l}\text { Positive/ } \\
n \text { tested }\end{array}$ & Prevalence & $95 \% \mathrm{CI}$ & Plasmodium Lineages $^{\dagger}$ \\
\hline \multirow[t]{14}{*}{ Passeriformes } & Turdidae & Song Thrush Turdus philomelos $(I)$ & $4 / 4$ & 1.00 & $0.51-1.00$ & LINN1(1), Elongatum(1) \\
\hline & Prunellidae & Dunnock Prunella modularis $(I)$ & $1 / 1$ & 1.00 & $0.21-1.00$ & \\
\hline & Turdidae & Blackbird Turdus merula $(I)$ & $28 / 34$ & 0.82 & $0.67-0.92$ & $\begin{array}{l}\text { LINN1(12), Elongatum(5), } \\
\text { SYAT05(4) }\end{array}$ \\
\hline & Fringillidae & Chaffinch Fringilla coeleps $(I)$ & $0 / 1$ & 0.00 & $0.00-0.79$ & \\
\hline & Fringillidae & Goldfinch Carduelis carduelis (I) & $0 / 1$ & 0.00 & $0.00-0.79$ & \\
\hline & Zosteropidae & Silvereye Zosterops lateralis $(N)$ & $7 / 33$ & 0.21 & $0.11-0.38$ & LINN1(2) \\
\hline & Rhipiduridae & Fantail Rhipidura fuliginosa $(N)$ & $0 / 4$ & 0.00 & $0.00-0.49$ & \\
\hline & Petroicidae & New Zealand Robin Petroica longipes $(E)$ & $4 / 100$ & 0.04 & $0.02-0.10$ & LINN1(1), Elongatum (3) \\
\hline & Petroicidae & Tomtit Petroica macrocephala toitoi $(E)$ & $0 / 3$ & 0.00 & $0.00-0.56$ & \\
\hline & Mohouidae & Whitehead Mohoua albicilla $(E)$ & $0 / 3$ & 0.00 & $0.00-0.56$ & \\
\hline & Acanthizidae & Grey Warbler Gerygone igata $(E)$ & $0 / 2$ & 0.00 & $0.00-0.66$ & \\
\hline & Meliphagidae & Bellbird Anthornis melanura $(E)$ & $0 / 1$ & 0.00 & $0.00-0.79$ & \\
\hline & Meliphagidae & Tui Prosthemadera novaeseelandiae $(E)$ & $0 / 1$ & 0.00 & $0.00-0.79$ & \\
\hline & & Total for all Passeriformes combined & $44 / 188$ & 0.23 & $0.18-0.30$ & $\begin{array}{l}\text { LINN1(16), Elongatum(9), } \\
\text { SYAT05(4) }\end{array}$ \\
\hline Anseriformes & Anatidae & Blue Duck Hymenolaimus malacorhynchos $(E)$ & $0 / 14$ & 0.00 & $0.00-0.22$ & \\
\hline Apterygiformes & s Apterygidae & Brown kiwi Apteryx mantelli $(E)$ & $1 / 20$ & 0.05 & $0.01-0.24$ & LINN1(1) \\
\hline
\end{tabular}

* whether an avian species is introduced $(I)$, native $(N)$, or endemic $(E)$ to New Zealand is shown in parenthesis behind the scientific name

$\uparrow$ the frequency with which Plasmodium lineages have been demonstrated for an avian species is shown in parentheses

Table 2. Packed cell volume (PCV) and body condition index (BCI) with standard errors (SE) for species with Plasmodium negative (neg) and positive (pos) birds.

\begin{tabular}{lllll}
\hline Species* & \multicolumn{2}{c}{ PCV\% $(\mathrm{SE})^{\dagger}$} & \multicolumn{2}{c}{ BCI $^{\ddagger}(\mathrm{SE})^{\dagger}$} \\
& neg birds & pos birds & Neg birds & Pos birds \\
\hline Blackbird Turdus merula $(I)$ & $44.3(2.3)$ & $43.9(0.9)$ & $2.72(0.06)$ & $2.65(0.06)$ \\
Silvereye Zosterops lateralis $(N)$ & $46.0(0.7)$ & $44.8(1.8)$ & $0.63(0.02)$ & $0.73(0.05)$ \\
New Zealand Robin Petroica longipes $(E)$ & $46.4(1.6)$ & $51.7(2.3)$ & $0.83(0.01)$ & $0.82(0.01)$
\end{tabular}

* whether an avian species is introduced $(I)$, native $(N)$, or endemic $(E)$ to New Zealand is shown in parenthesis behind the scientific name

$\uparrow$ standard error (SE) is shown in parenthesis behind the PCV and BCI values

$\$ \mathrm{BCI}$ is defined as bodyweight in grams divided by tarsus length in millimetres

nucleotide sequences of amplified DNA showed $>99 \%$ similarity with known sequences from GenBank as determined by NCBI BLAST. Plasmodium sp. lineage LINN1 (GenBank GQ471953) was found in blackbirds (12/21), silvereyes (2/2), song thrushes (Turdus philomelos) (1/2), NZ robins (1/4), and brown kiwi (1/20). Plasmodium elongatum lineage GRW06 (GenBank DQ368381) was found in blackbirds (5/21), song thrushes (1/2), and NZ robins (3/4), while $P$. sp. lineage SYAT05 (GenBank DQ847271) was found only in blackbirds (4/21) (Table 1). Plasmodium relictum lineage GRW4 (GenBank AY099041) was not found in any of the sequenced PCR products and thus has a maximum true prevalence range within the research area of $0-0.04$ in NZ robins, and of $0-0.02$ in all sampled avian species combined at the $95 \%$ confidence level. For the three detected lineages, the overall true prevalence at the $95 \%$ confidence level was $0.05-0.13$ for $P$. sp. lineage LINN1, 0.02-0.05 for $P$. elongatum lineage GRW06 and $0.01-0.05$ for $P$. sp. lineage SYAT05. The difference in prevalence between these lineages was significant $\left(\chi^{2}=9.04\right.$, d.f. $\left.=2, P=0.01\right)$.

Clinical data were further evaluated for bird species for which Plasmodium spp. positive as well as negative samples were found, comprising blackbirds, silvereyes and NZ robins. No significant differences in values for PCV and BCI were found between Plasmodium spp. negative and positive birds (Table 2), although in silvereyes a trend towards a better BCI in Plasmodium spp. positive birds was seen $(n=33, \mathrm{U}=$ $120.000, P=0.072$ ).

For the three bird species for which results were further analysed, accurate sex determination by visual inspection of plumage could only be performed for blackbirds, while accurate classification as juvenile or adult was possible for blackbirds and silvereyes. No significant difference in avian malaria prevalence was detected between male and female blackbirds (Fisher's exact, $P=0.51$ ), or between juvenile and adult blackbirds (Fisher's exact, $P=0.30$ ) or silvereyes (Fisher's exact, $P=1.00$ ).

\section{Discussion}

The aim of this study was to evaluate the presence and prevalence of avian malaria lineages in avian species within the Waimarino Forest area to aid assessment of the suitability of this location as a source site for NZ robin translocations. We identified three of the 17 Plasmodium lineages currently known in New Zealand, $P$. sp. lineage LINN1, P. elongatum lineage 
GRW06, and $P$. sp. lineage SYAT05. The establishment of avian Plasmodium lineages in an ecosystem and their consequent prevalence of infection in various bird species depend on multiple factors. Susceptibility and tolerance to infection of the avian hosts, presence and competence (transmission efficiency) of arthropod vectors, virulence of the Plasmodium spp., spatial and temporal distribution of host and vector, as well as climate, each play an important role (Benning et al. 2002; Bensch \& Åkesson 2003; Samuel et al. 2011; Westerdahl 2012). The severity of pathologic effects due to avian malaria infections differs between Plasmodium species (Lachish et al. 2011), but also between avian species (Palinauskas et al. 2008). Morbidity and mortality with malarial infections can be severe, especially in immunologically naïve and susceptible hosts, or when coinfections with other infectious agents, such as avipoxvirus or even intestinal parasites, are present (Graham et al. 2005; Alley et al. 2008, 2010; Atkinson \& Samuel 2010). Decreased activity and food consumption, pale mucous membranes, respiratory signs, vomiting and behavioural changes can be seen, signs that are caused by destruction of erythrocytes, inflammatory reactions predominantly in spleen, liver and lungs, and infiltration of parasites into the brain (Yorinks \& Atkinson 2000; Valkiunas 2005; Dunn et al. 2011).

For the Plasmodium lineages detected in the Waimarino Forest, information regarding their virulence and pathogenicity in New Zealand's wild bird species is limited. All three lineages detected in this study are common in exotic passerines, in which they are expected to have a relatively low pathogenicity, based on the high prevalence of chronic infections in apparently healthy birds (Tompkins \& Gleeson 2006). The lower prevalence in native and endemic bird species, combined with reported mortality cases, strengthens the belief that the impact on these New Zealand species is different (Tompkins \& Gleeson 2006; Ewen et al. 2012; Howe et al. 2012). One explanation might be that many endemic and native species, which did not evolve with the introduced Plasmodium spp., might have less immunocompetence to infection with these parasites, resulting in a lower percentage of infected birds surviving until the chronic phase of infection.

Plasmodium sp. lineage LINN1 (GenBank GQ471953) was detected most frequently in the widest range of bird species. To our knowledge, this is the first study to show the presence of $P$. sp. lineage LINN1 infection in native silvereyes and endemic NZ robins. Plasmodium sp. lineage LINN1 is a cosmopolitan generalist parasite and has been isolated from a wide range of avian species and mosquitoes throughout Europe, Asia and America (Bentz et al. 2006; Wood et al. 2007; Cosgrove et al. 2008; Kimura et al. 2010; Hellgren et al. 2011; Szoellosi et al. 2011; Ferraguti et al. 2013). Plasmodium sp. lineage LINN1 forms a cluster with the $99 \%$ genetically similar lineages $P$. sp. lineages AFTRU5 (GenBankDQ847263) and WA39 (GenBank EU810610), which have also been reported in New Zealand (Howe et al. 2012). Within New Zealand, the lineage LINN1 has been previously reported in blackbirds, great spotted kiwi, song thrush and bellbird (Anthornis melanura) (Ewen et al. 2012; Howe et al. 2012).

Plasmodium elongatum lineage GRW06 was the second most common lineage in our study and appears to be the most prevalent Plasmodium lineage in NZ robins from the Waimarino area. It is a cosmopolitan parasite with a wide host range, and has been detected in over 60 avian species of at least nine orders, including waterfowl (Anseriformes), raptors (Falconiformes), owls (Strigiformes) and particularly passeriformes, which are considered to act as reservoirs (Valkiunas 2005; Valkiunas et al.
2008). Within New Zealand, P. elongatum lineage GRW06 is considered the most common malarial parasite with the widest host range (Schoener et al. 2014). It is present throughout New Zealand (Baillie \& Brunton 2011) and has been described in the North Island saddleback (Philesturnus rufusater), South Island saddleback ( $P$. carunculatus), silvereye, brown kiwi, blackbird, house sparrow, songthrush, bellbird, yellowhammer (Emberiza citronella), whitehead (Mohoua albicilla), and NZ robin (Alley et al. 2010; Baillie \& Brunton 2011; Castro et al. 2011; Marzal et al. 2011; Ewen et al. 2012; Howe et al. 2012; Banda et al. 2013). In a captive rearing program of brown kiwi, an outbreak resulted in the death of one kiwi and parasitaemia in 25 out of $32(78 \%)$ of the concurrent captive population (Banda et al. 2013). Infection with this lineage has contributed to a high level of mortality in translocated South Island saddlebacks with concurrent avipox infection (Alley et al. 2010). This indicates that although the pathogenicity of the $P$. elongatum lineage GRW06 in exotic passerines appears to be moderate to low, its impact on endemic species can be severe.

Plasmodium sp. lineage SYAT05 was found only in blackbirds. This lineage is very closely related to the African lineages W38 (GenBank EU810633, MalAvi AFTRU08) and W37 (GenBank EU810632, MalAviAFTRU08) (Beadell et al. 2009). Hellgren et al. (2007) have reported the presence of $P$. sp. lineage SYAT05 in multiple passerine species from Africa and Europe, and in 13 species of intercontinental migrants. European blackbirds have a high prevalence of $P$. sp. lineage SYAT05, while lower prevalences were found in other European and American passerine species (Bentz et al. 2006; Dimitrov et al. 2010; Hellgren et al. 2011; Santiago-Alarcon et al. 2011). Within New Zealand, $P$. spp. lineage SYAT05 is a common lineage present in European blackbirds in the North Island; however, data regarding its geological spread in the South Island are lacking (Howe et al. 2012). Additionally, the $P$. sp. lineage SYAT05 has been isolated from kereru (Hemiphaga novaeseelandiae), tomtits (Petroica macrocephala), and bellbirds (Baillie \& Brunton 2011; Ewen etal. 2012; Howe et al. 2012). This lineage is considered to have low pathogenicity in exotic passerines, but it is currently unclear what effect $P$. sp. lineage SYAT05 has on the unique range of New Zealand's native and endemic species.

To evaluate the impact of Plasmodium infection on the birds' physical parameters, BCIs and PCVs were compared between Plasmodium spp. positive and negative blackbirds, silvereyes, and NZ robins, but no significant differences were found. Changes in PCV and BCI are more likely seen in the acute, high parasitaemia phase of infection, coinciding with an increased destruction of erythrocytes and reduced food intake (Moller \& Nielsen 2007). The Plasmodium positive birds we screened were likely in the chronic phase of infection, as studies suggest that acutely infected birds move around less, are more likely to be caught by predators and less likely to be captured in mist nets (Yorinks \& Atkinson 2000; Moller \& Nielsen 2007). It was interesting that in silvereyes we found a non-significant trend towards higher BCIs for Plasmodium infected birds compared with non-infected birds. It is plausible that in silvereyes a higher pre-infection weight to size ratio coincided with a more efficient immune response and a higher survival rate during the acute phase of infection (Atkinson et al 1995, Moller \& Saino 2004). An initial deterioration in BCI and PCV could have occurred in the acute phase of infection, followed by a return to the pre-infection condition once surviving birds reached a chronic, low parasitaemia 
phase. Nevertheless, as long as there are no existing data regarding the empirical validation of a relationship between BCI and survival of avian malaria in silvereyes, speculations regarding this association have to be made with extreme caution (Barnett et al. 2015). To confirm this theory, a higher number of birds would need to be tested (Power $=0.637$ in our analysis. G3Power 3.1.7), and a quantitative analysis of parasite load would need to be performed. The fact that all birds with positive PCR results for avian malaria were also in good physical condition suggests that they were either in the chronic or latent phase of infection, or that the infection was non-pathogenic.

Plasmodium relictum lineage GRW4, the lineage that raised concerns after it was identified in a NZ robin in 2011, was not found during this study. Because the geographical spread of $P$. relictum lineage GRW4 and its impact on New Zealand's endemic and native bird species are currently not well understood, bird translocations from areas where this lineage is confirmed to be established to areas that are potentially free of the linage GRW4 should be avoided. The absence of Plasmodium relictum lineage GRW4 in the 100 NZ robins and in the 144 birds of other species sampled during this study suggests that this lineage is either not established within the Waimarino Forest or that its prevalence in NZ robins in the area is less than $4 \%$.

In summary, the three Plasmodium lineages that we detected during this study are widespread throughout New Zealand, with a high prevalence in introduced bird species (Baillie \& Brunton 2011; Ewen et al. 2012; Howe et al. 2012), and $P$. relictum lineage GRW4 was not found in any of the tested birds. Based on our data, we contend that there is little chance of introducing Plasmodium lineages from the Waimarino Forest to new areas during NZ robin translocations. The high incidence of introduced bird species co-inhabiting with native and endemic species appears to create a melting pot for Plasmodium spp., an aspect of the Waimarino Forest that may be reflected in other ecosystems across New Zealand. Therefore, further research is needed to monitor the appearance of new pathogens in this area and to clarify the impact of Plasmodium spp. on endemic and native NZ bird species.

\section{Acknowledgements}

The handling of live birds during this research was approved by the Massey University Animal Ethics Committee (MUAEC protocol number 11/72) and the New Zealand Department of Conservation (DOC Permit no. 34781-FAU). Approval and support for this research project was given by the local land owners: Atihau-Whanganui Incorporation, Ngaporo Waimarino Forest Trust, Pipiriki Incorporation and Ernslaw One Limited. Various field teams worked under different NZ banding office permits (nos 2007022, 2010011, 2012007, 2012009, 2013003, 2013004, and 2013005). Financial support was received from The New Zealand Department of Conservation (DOC) and the PacificvetAvian Health Research Fund of the Institute of Veterinary, Animal and Biomedical Sciences (IVABS). Permission to include blue duck data in this study was granted by DOC. Nested PCR results for Plasmodium spp. for 20 kiwi samples were made available to us by Maungatautari Ecological Island Trust (MEIT). The final version of Figure 1 was created by Peter Lock (DOC, Whanganui District).

\section{References}

Alley MR, Fairley RA, Martin DG, Howe L, Atkinson T 2008. An outbreak of avian malaria in captive yellowheads/ mohua (Mohoua ochrocephala). New Zealand Veterinary Journal 56: 247-51.

Alley MR, Hale KA, Cash W, Ha HJ, Howe L 2010. Concurrent avian malaria and avipox virus infection in translocated South Island saddlebacks (Philesturnus carunculatus carunculatus). New Zealand Veterinary Journal 58: 218-23.

Armstrong DP 2010. Reintroduction Projects in New Zealand. http://www.massey.ac.nz/ darmstro/nz_projects.htm. (accessed 4 November 2014).

Atkinson CT, Woods KL, Dusek RJ, Sileo LS, Iko WM 1995. Wildlife disease and conservation in Hawaii: pathogenicity of avian malaria (Plasmodium relictum) in experimentally infected Iiwi (Vestiaria coccinea). Parasitology 111: S59-S69.

Atkinson CT, Samuel MD 2010. Avian malaria Plasmodium relictum in native Hawaiian forest birds: epizootiology and demographic impacts on 'apapane Himatione sanguinea. Journal of Avian Biology 41: 357-366.

Baillie SM, Brunton DH 2011. Diversity, distribution and biogeographical origins of Plasmodium parasites from the New Zealand bellbird (Anthornis melanura). Parasitology 138: 1843-1851.

Banda ME, Howe L, Gartrell BD, McInnes K, Hunter S, French NP 2013. A cluster of avian malaria cases in a kiwi management programme. New Zealand Veterinary Journal 61: 121-126.

Barnett CA, Suzuki TN, Sakaluk SK, Thompson CF 2015. Mass-based condition measures and their relationship with fitness: in what condition is condition? Journal of Zoology 296: 1-5.

Beadell JS, Covas R, Gebhard C, Ishtiaq F, Melo M, Schmidt BK, Perkins SL, Graves GR, Fleischer RC 2009. Host associations and evolutionary relationships of avian blood parasites from West Africa. International Journal for Parasitology 39: 257-266.

Benning TL, LaPointe D, Atkinson CT, Vitousek PM 2002. Interactions of climate change with biological invasions and land use in the Hawaiian Islands: Modeling the fate of endemic birds using a geographic information system. Proceedings of the National Academy of Sciences of the United States of America 99: 14246-14249.

Bensch S, Åkesson S 2003. Temporal and spatial variation of hematozoans in Scandinavian willow warblers. The Journal of Parasitology 89: 388-391.

Bensch S, Hellgren O, Perez-Tris J 2009. MalAvi: a public database of malaria parasites and related haemosporidians in avian hosts based on mitochondrial cytochrome $b$ lineages. Molecular Ecology Resources 9: 1353-1358.

Benson DA, Clark K, Karsch-Mizrachi I, Lipman DJ, Ostell J, Sayers EW 2014. GenBank. Nucleic Acids Research 42(D1): D32-D37.

Bentz S, Rigaud T, Barroca M, Martin-LaurentF, Bru D, Moreau J, Faivre B 2006. Sensitive measure of prevalence and parasitaemia of haemosporidia from European blackbird (Turdus merula) populations: value of PCR-RFLP and quantitative PCR. Parasitology 133: 685-692.

Bogich TL, Barker GM, Mahlfeld K, Climo F, Green R, Balmford A2012. Fragmentation, grazing and the speciesarea relationship. Ecography 35: 224-231. 
Brooks TM, Mittermeier RA, Mittermeier CG, da Fonseca GAB, Rylands AB, Konstant WR, Flick P, Pilgrim J, Oldfield S, Magin G and others C 2002. Habitat loss and extinction in the hotspots of biodiversity. Conservation Biology 16: 909-923.

Brown LD, T. Tony Cai TT, DasGupta A 2001. Interval estimation for a binomial proportion. Statistical Science 16: 101-117.

Castro I, Howe L, Tompkins DM, Barraclough RK, Slaney D 2011. Presence and seasonal prevalence of Plasmodium spp. in a rare endemic New Zealand passerine (Tieke or saddleback, Philesturnus carunculatus). Journal of Wildlife Disease 47: 860-867.

Cosgrove CL, Wood MJ, Day KP, Sheldon BC 2008. Seasonal variation in Plasmodium prevalence in a population of blue tits Cyanistes caeruleus. Journal of Animal Ecology 77: 540-548.

Craig J, Anderson S, Clout M, Creese B, Mitchell N, Ogden J, Roberts M, Ussher G 2000. Conservation issues in New Zealand. Annual Review of Ecology and Systematics: 61-78.

Dimitrov D, Zehtindjiev P, Bensch S 2010. Genetic diversity of avian blood parasites in SE Europe: Cytochrome $b$ lineages of the genera Plasmodium and Haemoproteus (Haemosporida) from Bulgaria. Acta Parasitologica 55: 201-209.

Dunn JC, Cole EF, Quinn JL 2011. Personality and parasites: sex-dependent associations between avian malaria infection and multiple behavioural traits. Behavioral Ecology and Sociobiology 65: 1459-1471.

Ewen JG, Bensch S, Blackburn TM, Bonneaud C, Brown R, Cassey P, Clarke RH, Perez-Tris J 2012. Establishment of exotic parasites: the origins and characteristics of an avian malaria community in an isolated island avifauna. Ecology Letters 15: 1112-1119.

Ferraguti M, Martinez-de la Puente J, Ruiz S, Soriguer R, Figuerola J 2013. On the study of the transmission networks of blood parasites from SW Spain: diversity of avian haemosporidians in the biting midge Culicoides circumscriptus and wild birds. Parasites and Vectors 6:208.

Graham AL, Lamb TJ, Read AF, Allen JE 2005. Malariafilaria coinfection in mice makes malarial disease more severe unless filarial infection achieves patency. Journal of Infectious Diseases 191: 410-421.

Heather BD, Robertson HA 2005. The field guide to the birds of New Zealand. Auckland, NZ, Viking Penguin.

Hellgren O, Waldenstrom J, Bensch S 2004. A new PCR assay for simultaneous studies of Leucocytozoon, Plasmodium, and Haemoproteus from avian blood. Journal of Parasitology 90: 797-802.

Hellgren O, Krizanauskiene A, Hasselquist D, Bensch S 2011. Low haemosporidian diversity and one key-host species in a bird malaria community on a Mid Atlantic Island (Sao Miguel, Azores). Journal of Wildlife Diseases 47: 849-859.

Hellgren O, Waldenstrom J, Perez-Tris J, Szollosi E, Hasselquist D, Krizanauskiene A, Ottosson U, Bensch S 2007. Detecting shifts of transmission areas in avian blood parasites - a phylogenetic approach. Molecular Ecology 16: 1281-1290.

Hitchmough R, Bull L, Cromarty P 2007. New Zealand Threat Classification System lists: 2005. Wellington, Department of Conservation.

Howe L, Castro IC, Schoener ER, Hunter S, Barraclough RK, Alley MR 2012. Malaria parasites (Plasmodium spp.) infecting introduced, native and endemic New Zealand birds. Parasitology Research 110: 913-923.

IUCN 2014. IUCN Red list of threatened species. Version 2014.2. http://www.iucnredlist.org (accessed 24 July 2014).

IUCN/SSC 2013. Guidelines for Reintroductions and Other Conservation Translocations. Version 1.0. Gland, Switzerland, IUCN Species Survival Commission. viiii $+57 \mathrm{p}$.

Kimura M, Darbro JM, Harrington LC 2010. Avian malaria parasites share congeneric mosquito vectors. Journal of Parasitology 96: 144-151.

Lachish S, Knowles SCL, Alves R, Wood MJ, Sheldon BC 2011. Fitness effects of endemic malaria infections in a wild bird population: the importance of ecological structure. Journal of Animal Ecology 80: 1196-1206.

Marzal A, Ricklefs RE, Valkiunas G, Albayrak T, Arriero E, Bonneaud C, Czirjak GA, Ewen J, Hellgren O, Horakova D and others 2011. Diversity, loss, and gain of malaria parasites in a globally invasive bird. Plos One 6(7): e21905. doi:10.1371/journal.pone.0021905.

Moller AP, Saino N 2004. Immune response and survival. Oikos 104: 299-304.

Moller AP, Nielsen JT 2007. Malaria and risk of predation: A comparative study of birds. Ecology 88: 871-881.

Myers N, Mittermeier RA, Mittermeier CG, da Fonseca GAB, Kent J 2000. Biodiversity hotspots for conservation priorities. Nature 403(6772): 853-858.

O'Donnell CFJ 1996. Predators and the decline of New Zealand forest birds: An introduction to the hole-nesting bird and predator programme. New Zealand Journal of Zoology 23: 213-219.

Ortiz-Catedral L, Prada D, Gleeson D, Brunton DH2011. Avian malaria in a remnant population of red-fronted parakeets on Little Barrier Island, New Zealand. New Zealand Journal of Zoology 38: 261-268.

Palinauskas V, Valkiunas GN, Bolshakov CV, Bensch S 2008. Plasmodium relictum (lineage P-SGS1): Effects on experimentally infected passerine birds. Experimental Parasitology 120: 372-380.

Parker KA, Brunton DH, Jakob-Hoff R 2006. Avian translocations and disease; implications for New Zealand conservation. Pacific Conservation Biology 12: 155-162.

Preacher KJ 2001. Calculation for the chi-square test: An interactive calculation tool for chi-square tests of goodness of fit and independence [Computer software]. Available from http://quantpsy.org.

Preacher KJ, Briggs NE 2001. Calculation for Fisher's Exact Test: An interactive calculation tool for Fisher's exact probability test for $2 \times 2$ tables [Computer software]. Available from http://quantpsy.org.

Reed C 1997. Avian Malaria in New Zealand Dotterel. Kokako 4: 3 .

Robertson HA, Dowding JE, Elliott GP, Hitchmough RA, Miskelly CM, O’Donnell CF, Powlesland RG, Sagar PM, Scofield RP, Taylor GA 2013. Conservation status of New Zealand birds, 2012. NZ Threat Classification Series 4. Wellington, Department of Conservation.

Samuel MD, Hobbelen PHF, DeCastro F, Ahumada JA, Lapointe DA, Atkinson CT, Woodworth BL, Hart PJ, Duffy DC 2011. The dynamics, transmission, and population impacts of avian malaria in native Hawaiian birds: a modeling approach. Ecological Applications 21: 2960-2973. 
Santiago-Alarcon D, Bloch R, Rolshausen G, Schaefer HM, Segelbacher G 2011. Prevalence, diversity, and interaction patterns of avian haemosporidians in a four-year study of blackcaps in a migratory divide. Parasitology 138: 824-835.

Schoener ER, Banda M, Howe L, Castro IC, Alley MR 2014. Avian malaria in New Zealand. New Zealand Veterinary Journal 62: 189-198.

Sekercioglu CH, Daily GC, Ehrlich PR 2004. Ecosystem consequences of bird declines. Proceedings of the National Academy of Sciences of the United States of America 101: 18042-18047.

Szoellosi E, Cichon M, Eens M, Hasselquist D, Kempenaers B, Merino S, Nilsson JA, Rosivall B, Rytkonen S, Toerek $\mathrm{J}$ and others 2011. Determinants of distribution and prevalence of avian malaria in blue tit populations across Europe: separating host and parasite effects. Journal of Evolutionary Biology 24: 2014-2024.

Taylor SS, Jamieson IG, Armstrong DP2005. Successful island reintroductions of New Zealand robins and saddlebacks with small numbers of founders. Animal Conservation 8: 415-420.

Tompkins DM, Gleeson DM2006. Relationship between avian malaria distribution and an exotic invasive mosquito in New Zealand. Journal of the Royal Society of New Zealand 36: 51-62.

Editorial board member: Craig Barnett

Received 22 May 2014; accepted 12 May 2015
Valkiunas G 2005. Avian malaria parasites and other haemosporidia. Boca Raton, Florida, USA, CRC Press. $934 \mathrm{p}$.

Valkiunas G, Zehtindjiev P, Dimitrov D, Krizanauskiene A, Iezhova TA, Bensch S 2008. Polymerase chain reactionbased identification of Plasmodium (Huffia) elongatum, with remarks on species identity of haemosporidian lineages deposited in GenBank. Parasitology Research 102: 1185-1193.

van RiperIII C, van Riper SG, Goff ML, Laird M 1986. The epizootiology and ecological significance of malaria in Hawaiian land birds. Ecological Monographs 56: 327-344.

Westerdahl H 2012. Quantitative disease resistance: to better understand parasite mediated selection on major histocompatibility complex. Proceedings of the Royal Society B: Biological sciences 279: 577-584.

Wood MJ, Cosgrove CL, Wilkin TA, Knowles SCL, Day KP, Sheldon BC 2007. Within-population variation in prevalence and lineage distribution of avian malaria in blue tits, Cyanistes caeruleus. Molecular Ecology 16: 3263-3273.

Yorinks N, Atkinson CT 2000. Effects of malaria on activity budgets of experimentally infected juvenile Apapane (Himatione sanguinea). Auk 117: 731-738. 